\title{
Public Private Partnership in Nigeria and Improvement in Service Delivery: An appraisal
}

\author{
Aliyu Idris, Sani Mustapha Kura, Mohammed U. Bashir \\ Ramat polytechnic, Maiduguri, Department of social services, P.M.B. 1070, Borno State, Nigeria. \\ Ramat polytechnic, Maiduguri, Department of social services, P.M.B. 1070, Borno State, Nigeria. \\ University of Maiduguri, Department of Sociology \& Anthropology, P.M.B.1069, Borno State, Nigeria.
}

\begin{abstract}
Public private partnership in Nigeria and other developing nations in Africa were adopted for the purposes of delivering services and infrastructural development. For PPP to work out successfully depends on how effective and positively disposed is the capitalist ruling elite or class in Nigeria. There is no denying the fact that Nigeria is controlled by a capitalist class for interest of the few rather than the many. The paper therefore concludes that the system has to be attuned to the wishes of the general public, and should also create institutions for promoting PPP and a well-functioning regulatory framework and more efficient public sector.
\end{abstract}

\section{Background of the Study}

The success of any government lies not just in the volume of its policies but rather the extent to which the policies have been implemented. Nigeria, over the years is characterized by large number of abandoned or uncompleted projects, and where completed they are greatly substandard. Public utilities and industries mostly perform below optimum levels revenues generated and or remitted are grossly inadequate with a substantial portion going into private pockets due to corruption. It is in the light of this dismal performance of the public sector projects and services, the high cost of executing them and the attendant corruption and mismanagement that the Nigeria government ventured into various forms of partnership with the private sector with a view to ameliorating most of the problems associated with public projects and service delivery in Nigeria.

\subsection{Statement of the Problem}

It is common knowledge that there is a serious dearth of infrastructure in Nigeria and that available is grossly inefficient both in terms of delivery as well as maintenance. The would bank recommends that $7-9$ percent of the GDP in developing countries be devoted to infrastructural development the late President Yaradua announced in 2010 that Nigeria needs more than us $\$ 19$ trillion to provide the needed adequate infrastructure. This amount can not be borne by the government. It therefore follows that the government alone can not even at its optimal level of revenue, satisfy the infrastructural needs of the society. Hence the need and necessity for a partnership of some sort between the government and the private sector with a view to combining resources to provide the infrastructure necessary for the social and economic development of the country. This is where the issue of public private partnership comes in.

This study sets out to understand the circumstances surrounding the adoption of public private partnership (PPP) in Nigeria with a view to explaining its objectives and modus -operandi. So doing will enable us determine its level of success and the likely problems or challenges; this would go a long way in assisting us proffer suggestion on the way forward.

\subsection{Objectives of the Study}

The objective of the study is to appraise public private partnership in the improvement of service delivery in Nigeria. Specifically, the objective of the study are to:-

i. $\quad$ To understand the concept of PPP

ii. To examine the reasons for its adoption in Nigeria

iii. To understand how PPP operate in Nigeria

iv. To identify the problems and achievements of PPP in Nigeria.

v. To make recommendations on the way forward.

\subsection{Research Questions}

In carrying out the study, the following questions will be asked.

i. What is Public private Partnership (PPP)?

ii. What are the reason for the introduction of PPP? 
iii. What are the various ways in which PPP manifests in Nigeria?

iv. What are the problems facing PPP in Nigeria?

v. What are the prospects and achievements of PPP in Nigeria?

vi. What are the suggestions on the ways to improving service delivery in Nigeria.

\subsection{Methodology}

This study relies heavily on existing literature is documents as its source of data. In this regard books, journal, scholarly articles and government publication on the subjects matter were consulted with a view to accomplishing the objectives stated in 1.3 above.

\subsection{Literature Review}

\section{The Need for Public Private Partnership}

Though there is no single, universally accepted definition for public-private partnerships, PPP are often termed to mean different things to different people, which can make assessing and comparing international experience in such partnerships difficult. In general, PPP refers to form of cooperation between public authorities and the private sector to finance, construct, renovate, manage, operate or maintain an infrastructure or service. At their core, all PPP involve some form of risk sharing between the public and private sector to provide the infrastructure or service. The allocation of sizable and, at times significant, elements of risk to the private partner is essential in distinguishing a PPP from the more traditional public sector model of public service delivery. There are two basic forms of PPP: contractual and institutional. Although institutional PPP have been quite successful in some circumstances, particularly in countries with well-developed institutional and regulatory capacities, contractual PPP are significantly more common, especially in developing economies.

Although there is no universal consensus about the definition of public-private partnerships, the following elements typically characterize a PPP: The infrastructure or service is funded, in whole or in part, by the private partner. Risks are distributed between the public partner and private partner and are allocated to the party best positioned to manage each individual risk. PPP are complex structures, involving multiple parties and relatively high transaction costs. PPP is a procurement tool where the focus is payment for the successful delivery of services (the performance risk is transferred to the private partner).

PPP is an output-/performance-based arrangement as opposed to the traditional input-based model of public service delivery where the focus is payment for the successful delivery of services. PPP typically involve bundled services (i.e., design, construction, maintenance and operation) to increase synergies and discourage low-capital/high operating-cost proposals. In general, PPP offer a new and dynamic approach to managing risk in the delivery of infrastructure and services. Although PPP is considered a new concept that has gained prominence in the last 20 years, PPP have actually been around for hundreds of years, wherever the private sector has been involved in the delivery of traditional public services (i.e., water, roads, rail and electricity).

In PPP arrangements, the private partner is typically compensated through either: User-based payments (i.e., toll roads, airport or port charges) Availability payments from the public authority [i.e., PFI], power purchase agreements (PPAs), water purchase agreements (WPAs) A combination of the above in user-based payment structures, the government or public authority often needs to provide some financial support to the project to mitigate specific risks, such as demand risk, or to ensure that full cost recovery is compatible with affordability criteria and the public's ability to pay. Government support mechanisms can take many forms, such as contributions, investments, guarantees and subsidies, but they should be carefully designed and implemented to allow for optimal risk allocation between the public and private sectors. When government supports are present, the objective is to increase private capital mobilization per unit of public sector contribution. Availability payments are at the heart of one form of PPP, the

This system provides capital assets for the provision of public services. Developed in the U.K., this model is used for a large number of infrastructure projects and gives the private sector strong incentives to deliver infrastructure and services on time and within budget. PFIs simultaneously allow governments and public authorities to spread the cost of public infrastructure projects over several decades. This creates greater budget certainty, while also liberating scarce public resources for other social priorities. Government Support Mechanisms hosting governments can provide financial support to or reduce the financial risk of a project in many ways. Common forms of government support mechanisms include:

(a) Cash subsidy: The government or public authority agrees to provide a cash subsidy to a project. It can be a total lump sum or a fixed amount on a per unit basis, and payments can be made either in installments or all at once. Payment guarantee: The government agrees to fulfill the obligations of a purchaser (typically a publicly owned enterprise) with respect to the private entity in the case of non-performance by the purchaser. The most common example of this is when a government guarantees the fixed payment of an off-take agreement (e.g., PPA or WPA) between a private entity and the publicly owned enterprise. 
(b) Debt guarantee: The government secures a private entity's borrowings by guaranteeing repayment to creditors in case of default. Revenue guarantee: The government sets a minimum variable income for the private partner; typically this income is from customer user fees. This form of guarantee is most common in roads with minimum traffic or revenue set by a government.

\section{The Need for Public Private Partnership}

The delivery of services and availability in Nigeria is generally poor. Services provided are inferior and financing system for infrastructure increase, maintenance and repair is inadequate. These problems are exacerbated by rapid urbanization. Effective and efficient urban for infrastructure and services provision are important in delivering major benefits in economic growth, poverty alleviation, environmental sustainability and sustainable development in general. African countries and Nigeria in particular need to improve basic services such as water, sanitation, waste management, transport infrastructure, health services etc so as to meet the needs of more people. Better service delivery is crucial for sustainable growth, development and poverty reduction. It increases people's standards of living and contributes to sustainable development.

Public sector provision of these services however has proved to be inadequate and unsustainable due to, inter-alia, the nature of the public sector. Until very recently the sector has been typically characterized by inefficiency and lack of effectiveness, leading to poor performance. This in turn can be attributed to many closely inter-linked and self-reinforcing characteristics of the sector like political interference; unclear objectives; limited operational autonomy; inadequate managerial skills vis a vis technical, human, conceptual and design skills; inadequate accountability and transparency; heavy and cumbersome bureaucracy; poor workers' morale; inappropriate economic settings; inadequate capital and lack of appreciation of the free interplay of the market forces of supply and demand. Such a sector therefore is inadequate in the whole exercise of effectively, efficiently and sustainable producing, rendering and improving the needed quantity and quality of goods and services. It is in the find a way of remedying the situation that public private partnership can to being.

Public Private Partnership (PPP) Project means a project based on a contract or concession agreement, between a Government or statutory entity on the one side and a private sector company on the other side, for delivering an infrastructure service on payment of user charges.

Private Sector Company means a company in which $51 \%$ or more of the subscribed and paid up equity is owned and controlled by a private entity.

While there is no single definition of PPPs, they broadly refer to long-term, contractual partnerships between the public and private sector agencies, specifically targeted towards financing, designing, implementing, and operating infrastructure facilities and services that were traditionally provided by the public sector. These collaborative ventures are built around the expertise and capacity of the project partners and are based on a contractual agreement, which ensures appropriate and mutually agreed allocation of resources, risks, and returns. PPPs do not mean reduced responsibility and accountability of the government. They still remain public infrastructure projects committed to meeting the critical service needs of citizens. The government remains accountable for service quality, price certainty, and cost-effectiveness (value for money) of the partnership. Government remains actively involved throughout the project's life cycle. Under the PPP format, the government role gets redefined as one of facilitator and enabler, while the private partner plays the role of financier, builder, and operator of the service or facility. PPPs aim to combine the skills, expertise, and experience of both the public and private sectors to deliver higher standard of services to customers or citizens. The public sector contributes assurance in terms of stable governance, citizens' support, financing, and also assumes social, environmental, and political risks. The private sector brings along operational efficiencies, innovative technologies and managerial effectiveness, access to additional finances, and construction and commercial risk sharing.

Not all projects with private sector participation are PPP projects. Essentially, PPPs are those ventures in which the resources required by the project in totality, along with the accompanying risks and rewards/returns, are shared on the basis of a predetermined, agreed formula, which is formalized through a contract. PPPs are different from privatization. While PPPs involve private management of public service through a long-term contract between an operator and a public authority, privatization involves outright sale of a public service or facility to the private sector. A typical PPP example would be a toll expressway project financed and constructed by a private developer.

A PPP project is essentially based on a significant opportunity for the private sector to innovate in design, construction, service delivery, or use of an asset, To be viable, PPPs need to have clearly defined outputs, avenues for generating nongovernmental revenue, and sufficient capacity in the private sector to successfully deliver project objectives.

In a PPP, the 'private' partner could be a private company, a consortium, or a nongovernmental organization (NGO). Typically, a PPP project involves a public sector agency and a private sector consortium which comprises contractors, maintenance companies, private investors, and consulting firms. The consortium 
often forms a special company or a 'special purpose vehicle' (SPV). The SPY signs a contract with the government and with the subcontractors to build the facility and then maintain it.

The PPP is operationalized through a contractual relationship between a public body (the conceding authority) and a private company (the concessionaire). This partnership could take many contractual forms, which progressively vary with increasing risk, responsibility, and financing for the private sector. These contracts are usually financed by user fees or tariffs or government subsidies.

The public sponsor of the PPP decides the degree of private participation required for the particular project. This decision is usually based on the government's objectives of undertaking the project, the degree of control it desires, and the ability of the PPP consortium to deliver the required service. It is also influenced by the provisions of the existing legal and regulatory framework, the structuring of the project to attract private resources, and the potential to generate future cash flows.

PPPs often involve complex planning and sustained facilitation. Infrastructure projects such as roads and bridges, water supply, sewage and drainage involving large investment, long gestation period, poor cost recovery, and construction, social, and environmental risks. When infrastructure is developed as PPPs, the process is often characterized by detailed risk and cost appraisal, complex and long bidding procedures, difficult stakeholder management, and long-drawn negotiations to financial closure. This means that PPPs are critically dependent on sustained and explicit support of the sponsoring government. To deal with these procedural complexities and potential pitfalls of PPPs, governments need to be clear, committed, and technically capable to handle the legal, regulatory, policy, and governance issues.

\section{Types of Public Private Partnership:}

There can be several different types of P3's which form a spectrum, in terms of risk allocated differently between the private and public sector partnership Build-operate-transfer (BOT), build-own-operate (BOO), build-own-operate-transfer (BOOT), design-building-finance-operate (DBFO) and similar arrangements are contracts specifically designed for new projects or investments in facilities that require extensive rehabilitation. Under such arrangements, the private partner typically designs, constructs and operates facilities for a limited period from 15 to 30 years, after which all rights or title to the assets are relinquished to the government. Under a build-operate-own (BOO) contract, the assets remain indefinitely with the private partner. The government will typically pay the BOT partner at a price calculated over the life of the contract to cover its construction and operating costs, and provide a reasonable return.

\section{Build/Operate/Transfer (BOT) Orbuild/Transfer/ Operate (BTO):}

The private partner builds a facility to the specifications agreed to by the public agency, operates the facility for a specified time period under a contract or franchise agreement with the agency, and then transfers the facility to the agency at the end of the specified period of time. In most cases, the private partner will also provide some, or all, of the financing for the facility, so the length of the contract or franchise must be sufficient to enable the private partner to realize a reasonable return on its investment through user charges.

At the end of the franchise period, the public partner can assume operating responsibility for the facility, contract the operations to the original franchise holder, or award a new contract or franchise to a new private partner. The BTO model is similar to the BOT model except that the transfer to the public owner takes place at the time that construction is completed, rather than at the end of the franchise period.

\section{Build-own-Operate (BOO):}

The contractor constructs and operates a facility without transferring ownership to the public sector. Legal title to the facility remains in the private sector, and there is no obligation for the public sector to purchase the facility or take title. A BOO transaction may qualify for tax-exempt status as a service contract if all Internal Revenue Code requirements are satisfied.

\section{Buy-build Operate (BBO):}

BBO is a form of asset sale that includes a rehabilitation or expansion of an existing facility. The government sells the asset to the private sector entity, which then makes the improvements necessary to operate the facility in a profitable manner.

\section{Contract Services Operations and Maintenance:}

A public partner (federal, state, or local government agency or authority) contracts with a private partner to provide and/or maintain a specific service. Under the private operation and maintenance option, the public partner retains ownership and overall management of the public facility or system. 


\section{Operations, Maintenance, \& Management}

A public partner (federal, state, or local government agency or authority) contracts with a private partner to operate, maintain, and manage a facility or system proving a service. Under this contract option, the public partner retains ownership of the public facility or system, but the private party may invest its own capital in the facility or system. Any private investment is carefully calculated in relation to its contributions to operational efficiencies and savings over the term of the contract. Generally, the longer the contract term, the greater the opportunity for increased private investment because there is more time available in which to recoup any investment and earn a reasonable return. Many local governments use this contractual partnership to provide wastewater treatment services.

\section{Design-build:}

A DB is when the private partner provides both design and construction of a project to the public agency. This type of partnership can reduce time, save money, provide stronger guarantees and allocate additional project risk to the private sector. It also reduces conflict by having a single entity responsible to the public owner for the design and construction. The public sector partner owns the assets and has the responsibility for the operation and maintenance.

\section{Design Build Maintain:}

A DBM is similar to a DB except the maintenance of the facility for some period of time becomes the responsibility of the private sector partner. The benefits are similar to the

DB with maintenance risk being allocated to the private sector partner and the guarantee expanded to include maintenance. The public sector partner owns and operates the assets.

\section{Design build operate:}

A single contract is awarded for the design, construction, and operation of a capital improvement. Title to the facility remains with the public sector unless the project is a design/build/operate/transfer or design/build/own/operate project. The DBO method of contracting is contrary to the separated and sequential approach ordinarily used in the United States by both the public and private sectors. This method involves one contract for design with an architect or engineer, followed by a different contract with a builder for project construction, followed by the owner's taking over the project and operating it.

A simple design-build approach creates a single point of responsibility for design and construction and can speed project completion by facilitating the overlap of the design and construction phases of the project. On a public project, the operations phase is normally handled by the public sector under a separate operations and maintenance agreement. Combining all three passes into a DBO approach maintains the continuity of private sector involvement and can facilitate private-sector financing of public projects supported by user fees generated during the operations phase.

\section{Developer Finance:}

The private party finances the construction or expansion of a public facility in exchange for the right to build residential housing, commercial stores, and/or industrial facilities at the site. The private developer contributes capital and may operate the facility under the oversight of the government. The developer gains the right to use the facility and may receive future income from user fees.

While developers may in rare cases build a facility, more typically they are charged a fee or required to purchase capacity in an existing facility. This payment is used to expand or upgrade the facility. Developer financing arrangements are often called capacity credits, impact fees, or extractions. Developer financing may be voluntary or involuntary depending on the specific local circumstances.

\section{Enhanced use leasing (EUL):}

An EUL is an asset management program in the Department of Veterans Affairs (VA) that can include a variety of different leasing arrangements (e.g. lease/develop/operate, build/develop/operate). EULs enable the VA to long-term lease VA-controlled property to the private sector or other public entities for non-VA uses in return for receiving fair consideration (monetary or in-kind) that enhances VA's mission or programs

\section{Lease Develop Operate (LDO) or Build Develop Operate (BDO):}

Under these partnerships arrangements, the private party leases or buys an existing facility from a public agency; invests its own capital to renovate, modernize, and/or expand the facility; and then operates it under a contract with the public agency. A number of different types of municipal transit facilities have been leased and developed under LDO and BDO arrangements. 


\section{Lease purchase:}

A lease/purchase is an installment-purchase contract. Under this model, the private sector finances and builds a new facility, which it then leases to a public agency. The public agency makes scheduled lease payments to the private party. The public agency accrues equity in the facility with each payment. At the end of the lease term, the public agency owns the facility or purchases it at the cost of any remaining unpaid balance in the lease.

Under this arrangement, the facility may be operated by either the public agency or the private developer during the term of the lease. Lease/purchase arrangements have been used by the General Services Administration for building federal office buildings and by a number of states to build prisons and other correctional facilities.

\section{Sale Leaseback:}

This is a financial arrangement in which the owner of a facility sells it to another entity, and subsequently leases it back from the new owner. Both public and private entities may enter into sale/leaseback arrangements for variety of reasons. An innovative application of the sale/leaseback technique is the sale of a public facility to a public or private holding company for the purposes of limiting governmental liability under certain statues. Under this arrangement, the government that sold the facility leases it back and continues to operate it.

\section{Tax Exempt Lease:}

A public partner finances capital assets or facilities by borrowing funds from a private investor or financial institution. The private partner generally acquires title to the asset, but then transfers it to the public partner either at the beginning or end of the lease term. The portion of the lease payment used to pay interest on the capital investment is tax exempt under state and federal laws. Tax-exempt leases have been used to finance a wide variety of capital assets, ranging from computers to telecommunication systems and municipal vehicle fleets.

\section{Turnkey:}

A public agency contracts with a private investor/vendor to design and build a complete facility in accordance with specified performance standards and criteria agreed to between the agency and the vendor. The private developer commits to build the facility for a fixed price and absorbs the construction risk of meeting that price commitment. Generally, in a turnkey transaction, the private partners use fast-track construction techniques (such as design-build) and are not bound by traditional public sector procurement regulations. This combination often enables the private partner to complete the facility in significantly less time and for less cost than could be accomplished under traditional construction techniques.

In a turnkey transaction, financing and ownership of the facility can rest with either the public or private partner. For example, the public agency might provide the financing, with the attendant costs and risks. Alternatively, the private party might provide the financing capital, generally in exchange for a long-term contract to operate the facility.

\subsection{Benefits of Public Private Partnership:}

Public-Private Partnership is a contractual agreement between a public agency (federal, state or local) and a private sector entity. Through this agreement, the skills and assets of each sector (public and private) are shared in delivering a service or facility for the use of the general public. In addition to sharing the resources, each party shares the potential risks and rewards in the delivery of the public service and/ or facility. Sectors where PPPs have been used successfully are transportation, water/ wastewater management, urban planning, infrastructure and utility development, financial management and education.

The Public-Private Partnership projects are long-term partnerships (typical projects have the duration between 20 and 40 years). Another distinctive feature of the PPP projects is the fact that the private partner carries the risk for the invested capital, not the public sector, as it is the case of projects based on outsourcing. PPP projects enable the risk to be optimally spread, and each subject of the partnership to take the risks they are able to manage best.

Another specific characteristic is that, differently from other types of projects where the public sector enters into co-operation with the private sector, the outputs of this co-operation are defined from the beginning. Therefore, on one side, the public sector exactly specifies the type of the service the private sector has to provide, its quality, the price and the control mechanisms. On the other side, the private sector implements the entire project by ensuring its funding and maintenance. The basic implementation condition of a PPP project is its ability to achieve, from the point of view of the public sector, a greater benefit in relation to the expenditures, 
compared with the situation when the public sector implements the given project by itself, using its own forces and from its own sources, i.e. respecting the principle of value for money.

The advantages of Public Private Partnerships (PPP's) include the following:

- Speedy, efficient and cost effective delivery of projects.

- Value for money for the taxpayer through optimal risk transfer and risk management.

- Efficiencies from integrating design and construction of public infrastructure with financing, operation and maintenance/upgrading.

- Creation of added value through synergies between public authorities and private sector companies, in particular, through the integration and cross transfer of public and private sector skills, knowledge and expertise.

- Alleviation of capacity constraints and bottlenecks in the economy through higher productivity of labour and capital resources in the delivery of projects.

- Competition and greater construction capacity (including the participation of overseas firms, especially in joint ventures and partnering arrangements).

- Accountability for the provision and delivery of quality public services through performance incentive management/regulatory regime.

- Innovation and diversity in the provision of public services.

- Effective utilization of state assets to the benefit of all users of public services.

- Faster implementation.

The allocation of design and construction responsibility to the private sector, combined with payments linked to the availability of a service, provides significant incentives for the private sector to deliver capital projects within shorter construction timeframes.

\section{Better Risk Allocation}

A core principle of any PPP is the allocation of risk to the party best able to manage it at least cost. The aim is to optimize rather than maximize risk transfer, to ensure that best value is achieved.

\section{Acceleration of Infrastructure}

PROVISION: PPP often allows the public sector to translate upfront capital expenditure into a flow of ongoing service payments. This enables projects to proceed when the availability of public capital may be constrained (either by public spending caps or annual budgeting cycles), thus bringing forward much needed investment.

\section{Reduced Whole Life Costs}

PPP projects which require operational and maintenance service provision provide the private sector with strong incentives to minimize costs over the whole life of a project, something that is inherently difficult to achieve within the constraints of traditional public sector budgeting.

\section{Improved Quality Of Service}

International experience suggests that the quality of service achieved under a PPP is often better than that achieved by traditional procurement. This may reflect the better integration of services with supporting assets, improved economies of scale, the introduction of innovation in service delivery, or the performance incentives and penalties typically included within a PPP contract.

In most countries, the rationale to undertake projects e.g. e-government and ICT are compelling. All levels of government require modernization, new technologies, better efficiency, and improved services for citizens and customers. However, many of the upgrades and modernization required is not only capital intensive and expensive, but is also complex to manage and outside of the scope and skill-set of most government agencies. By having the private sector perform an e-government or ICT service, on behalf of the government, a potential "win-win" solution can be realized. Where the private sector finances and operates a system, the government is in a better position to "ensure" effective delivery of the service, and the customer/citizen is receiving a higher quality service and is engaged more constructively in customer interfaces with the public sector.

In Nigeria and other developing countries, sustainable access to healthcare and other socio-economic services and products can be accomplished through public-private partnerships, where the government delivers the minimum standard of services, products and or care, the private sector brings skills and core competencies, while donors and business bring funding and other resources. Such collaborations will be especially productive in promoting poverty alleviation through micro-finance, enhancing health through partnerships as has been the case with polio eradication and other child immunization efforts.

The contribution of PPP in the society cannot be underestimated as it is useful in almost all aspects of life for example PPP can be useful in high priority projects as it helps in accelerating the implementation of 
these projects for which the administrations have a lack of funds, there is also the fact that services. PPP encourages very rapid provision and less expensive. PPP is all encompassing as it is even useful in economy solutions because it helps boost economic growth through the investment of the private sector.

Infrastructure is the basic physical and organizational structures needed for the operation of a society or enterprise, or the services and facilities necessary for an economy to function. The term typically refers to the technical structures that support a society, such as roads, water supply, sewers, electrical grids, telecommunications, and so forth. Viewed functionally, infrastructure facilitates the production of goods and services; for example, roads enable the transport of raw materials to a factory, and also for the distribution of finished products to markets and basic social services such as schools and

hospitals. In military parlance, the term refers to the buildings and permanent installations necessary for the support, redeployment, and operation of military forces.

Encompassing all things to all people is hardly a useful way to define infrastructure -clouding investors, governments, and their citizens' ability to understand, advocate, and direct capital toward durable, networked assets with widespread societal benefits. Primary infrastructure components are generally monopolistic in nature and require large financial commitments for their development, repair and replacement. They can be built, touched, enabled, disabled, and function together to form interrelated, dependent systems that deliver needed commodities and services to society. In doing so, they facilitate economic productivity and promote a standard of living. Infrastructure can then be more concisely defined as 'the physical components of interrelated systems providing commodities and services essential to enable, sustain, or enhance societal living conditions'.

The development and maintenance of essential public infrastructure is an important ingredient for sustained economic growth and poverty reduction. Poor infrastructure is perhaps the most binding constraint to growth throughout the Asia-Pacific region. Infrastructure investment can lift economic growth and support social objectives.

Health, education, and efficient water and sanitation services help lay the groundwork for a more productive, healthy population capable of contributing to sustained economic growth. Likewise transport infrastructure improves access to services and markets in rural areas.

\subsection{Problems and Challenges of Public Private Partnership}

A common problem with PPP projects is that private investors obtained a rate of return that was higher than the government's bond rate, even though most or all of the income risk associated with the project was borne by the public sector.

It is certainly the case that government debt is cheaper than the debt provided by finance PFI projects, and cheaper still than the overall cost of finance for PFI projects, i.e. the weighted average cost of capital (WACC). This is of course to attempt to compare incompatible and incomplete economic circumstances. It ignores the position of taxpayers who play the role of equity in this financing structure. Making a simple comparison, however, between the government's cost of debt and the private sector WACC implies that the government can sustainable fund projects at a cost of finance equal to its risk-free borrowing rate. This would be true only if existing borrowing levels were below prudent limits. The constraints on public borrowing suggests, nevertheless, that borrowing levels are not currently too low in most countries. These constraints exist because government borrowing must ultimately be funded by the taxpayers. Assessment procedures were incorporated in the private finance initiative and its Australian counterparts from the late 1990s onwards (Johnson, 2009)

In 2009, the New Zealand Treasury, in response to inquiries by the new National Party government, released a report on PPP schemes that concluded that" there is little reliable empirical evidence about the costs and benefits of PPPs" and that there are other ways of obtaining private sector finance, as well as that the advantages of PPPs must be weighted against the contractual complexities and rigidness they entail (Briant,).

Nowadays, a new model is also being discussed, called the Public-Private Community Partnership (PPCP) model, wherein both the government and private players work together for social welfare, showing the prime focus of private players on profit. This model is being applied more in developing nations such as India. Success is being achieved through this model too; it mainly helps to ramp up the development process as the focus is shifted towards target achievement rather than profit achievement.

\section{Conclusion}

Based on findings of the study, there is no denying the fact that Nigeria slow development is largely on consequence of its underdeveloped infrastructure, poridging the gap should therefore, be a top priority of the Nigerian government achieving the improvement in service delivery rests on certain factors; institutional and other related mechanisms that will drive the initiative will have to be put in place. Measures such as improved business environment, well-functioning regulatory framework and more efficient public sector will be crucial to the achievement of the gains of PPP. 


\section{Recommendation}

To address the perceived constraints in the implementation and improvement in service delivery in Nigeria, we suggest the following.

1. Fiscal benefit in terms of tax holiday to infrastructure project and tax incentives to investors should be provided by government.

2. Systematic compilation, analysis and experiences should be made available and the same be provided on the website which has been recently launched by the government to exclusively devoted to PPPs . this will facilitate quicker assimilation and dissemination of best practices to various levels of government.

3. A well-functioning regulatory framework and more efficient public sector should be put in place.

4. Institutions should be created solely for the purpose of promoting PPP projects at the federal and state level.

5. A robust transparent evaluation mechanism should be provided to ensure that PPP programme are delivering services and/or value for money.

\section{References}

[1]. Abah, N.C. (1997) Public Personnel Administration, Enugu: JOEN Associates

[2]. Azhar, E (1999) Fundamentals of Organisational Behaviour, London: Routledge.

[3]. Bobbit J and Behling H (1972) Guidelines for preparing Research Proposals New Yourk: University Press.

[4]. Braint, U.B (2010) Management, Principles and Practice, New Yourk: McGraw Hills.

[5]. Chukwuemeka, E (2006) Administration and Politics in Nigeria,

[6]. Chukwuemeka, E (2008) Principles of Human Resources and Personnel Management in Nigeria, Enugu: Providence Publishers.

[7]. Chukwuemeka, E (2011) The Substance of Public Administration A Compendium Of Public Policy and Local Government, Berlin: Lambart Academic Publishing.

[8]. Chukwuemeka, E, Abah N.C., Eze, O (1998) Public Administration and Development: The Nigerian Experience, Enugu: Marydan Publishers.

[9]. Commonwealth (2003) "Public - Private Partnerships: A Review with Special Reference to Local Government" in Commonwealth Local Government Handbook. KPL. Rochester partner

[10]. Daniel Roth (2010) A Matter of Time; Will the Credit Crisis Impact Canadian P3s?, Managing Director Infrastructure Advisory Practice, Ernst and Young. Canadian Council for Public-Private

Partnerships.http://www.pppcouncil.ca/pdfmatteroftime.pdfAccessed 22 May 2010

[11]. Egbewole Q. A. (2011) Examining Public Private Partnership In Nigeria: Potentials And Challenges ; Being A B.Sc Long Essay Submitted To The Department Of Common Law, Faculty Of Law, University Of Ilorin, Ilorin, Nigeria

[12]. Hall and Neugarim (1986) The Functions of Management, New York: McGraw Hills.

[13]. Heather Fussell and Charley Beresford (2009) Public-Private Partnerships: Understanding the Challenge

[14]. Herzberg F (1988) One more Time, How do you motivate employees, Havard Business Review 4(6) 71-80.

[15]. Jackson, U (2009) The difference between executive's and subordinate's and subordinate's view on motivation, Journal of Management Studies, 5(1) 23-29.

[16]. Jacobs, S (2009) What motivates workers, African Journal of Business Studies 5(2) 31 - 40.

[17]. Johnson, W (2010) Public Enterprises, engine of development, International journal of Sustainable Development, 4(2) 51-59.

[18]. Lewis, N (2006) Why government organizations fail, International Journal of Administration, 3(4) 45-51.

[19]. Nwizu G.C. (2008) "Management of Public Enterprises and Co-operatives: A multi-disciplinary approach" Enugu: Agmasum printers and publishers

[20]. Nwizu G.C. (2010) "Studies in Modern Public Administration" Okigwe: Whytem Prints

[21]. Nwizu, C (1997) Organization, Basic problems, Principles and Theories, Enugu John Jacob Classic Publishers.

[22]. Obozuwa, D. (2011) PPP as a tool for infrastructure development in Nigeria (1) Business Day of October 2011

[23]. Odo U (2010) The Advantages of privatization in a depressed economy, Journal of Economics and Finance, 1(1) 30-39.

[24]. Okanya, D (1996) Great Issues in Nigerian Government, Enugu: Marydan Marydan Publishers.

[25]. Osisioma B, and Osisioma H, (2002) Management practice, manual for The professional management students, Enugu: JBH Publications.

[26]. Partnerships British-Colombia (2003) An Introduction to Public Private Partnerships; www.pannershipsbc.ca past, Present and Issues, Lagos: Vinez Publishers.

[27]. Public private partnership (1999) A guide for Local Government prepared by the British Colombia Ministry of Municipal Affairs

[28]. Sohail, M., Plummer, J., Slater, R., and Heymans, C.(2003) Local Government Service Partnerships: A Background'. (Commonwealth Local Government Conference. Pretoria, South Africa

[29]. Toby Sanger, Corina Crawley. (2009)Hie Problem with Public-Private Partnerships Economic crisis exposes the high costs and risks of P3s by National Office. The Monitor Issue(s): Public services and privatization.

[30]. U. S. Pant, Chief controller of Accounts. Ministries of Urban Development; Urban employment \& Poverty Alleviation, Government of India Relevance of public private partnership public construction being a paper presented at the International conference in New Delhi; 150 years of the CPWD.

[31]. Ubeku, A (1976) Personnel Management in Nigeria, Benin City: Ethiope Publishers.

[32]. Ugo, B (2011) Why the private sector survive, journal of policy and Development Studies, 2(2) $65-66$.

[33]. Yoder, D (1977) The Human Side of Enterprise, New York: McGraw Hill. 